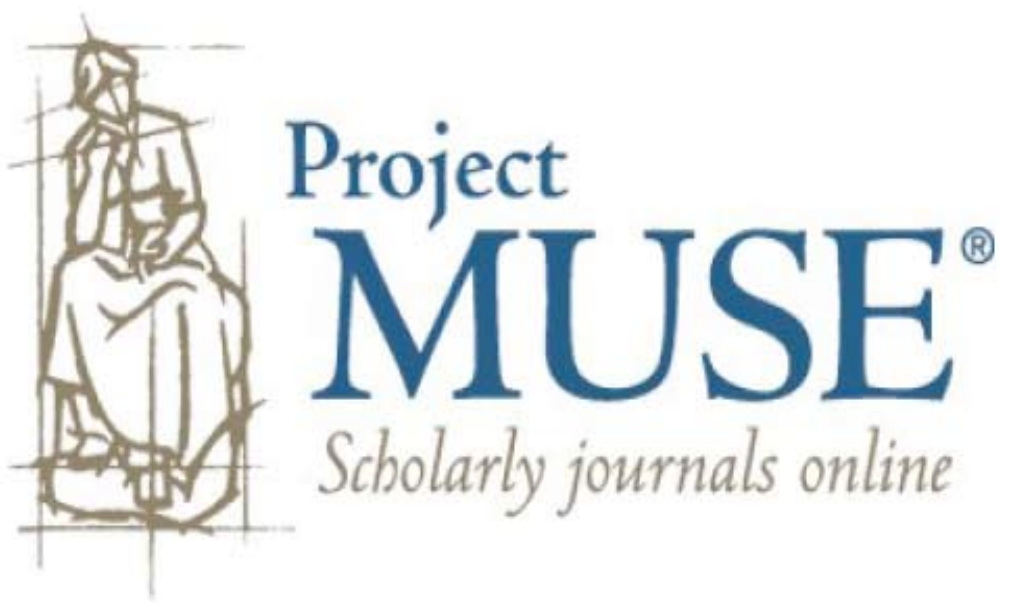




\title{
Is Natural Slavery Beneficial?
}

\author{
TH ORNTON C. L O C K W O O D, JR.*
}

SLAVERY IS THE DARK SHADOw cast upon Aristotle's Politics. ${ }^{\text {I }}$ No doubt, Aristotle's qualified defense of slavery seems indefensible to modern readers insofar as it denies the infinite intrinsic worth which today we ascribe to each and every autonomous human being. But, to add insult to injury, commentators have located problems within Aristotle's treatment of slavery which make his defense, in the late Bernard Williams' words, "a disaster" and proof that, "if there is something worse than accepting slavery, it consists in defending it." ${ }^{2}$ To seize upon one major inconsistency: according to the Eudemian and Nicomachean Ethics, master and slave

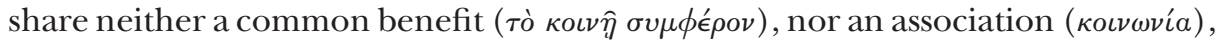
and their relationship manifests neither friendship nor justice. ${ }^{3}$ Indeed, the Ethics depicts the relationship between master and slave as an illustration of the extent to which friendship and justice are absent in a tyranny. ${ }^{4}$ Such remarks seem to conflict with the account of slavery in Politics I, where Aristotle distinguishes and juxtaposes masterly and political rule in order to disprove the claim that "the same person has expertise in political rule, kingly rule, household rule, and the

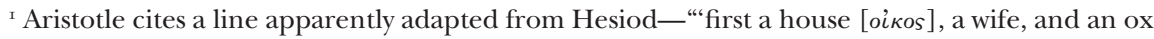

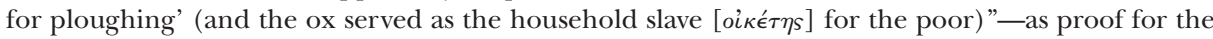
necessity of servants within the household (oıкía). See Hesiod, Works and Days (Oxford: Clarendon, I978), 405; Pol. I.2: I 252 bI I-I 2; Oec. I.2: I343a22. Cf. Pol. VI.8: I323a5-6. (Throughout this paper, unless otherwise indicated, translations of the Ethics and Politics are my own, based on the Greek texts of Bywater, Aristotelis Ethica Nicomachea [Oxford: Clarendon, I 894], Ross, Aristotelis Politica [Oxford: Clarendon, I957], and Walzer and Mingay, Aristotelis Ethica Eudemia [Oxford: Clarendon, I99 I]. I am much indebted to the translations of Irwin, Rackham, and Simpson. Unless indicated otherwise, all references inserted within the text are to the Bekker page numbers of Aristotle's texts.) Although Aristotle's ideal city ultimately includes non-Hellenic slaves, in general, Aristotle prefers private as opposed to public slaves, and most likely far fewer in number than existed in Athens in his time. See W. L. Newman, The Politics of Aristotle [Politics] (Oxford: Oxford University Press, I 887), vol. I, I38-58; D. B. Nagle, The Household as the Foundation of Aristotle's Politics [Household] (Cambridge: Cambridge University Press, 2006), IO2-I 7; and J. Ober, Political Dissent in Democratic Athens [Political Dissent] (Princeton: Princeton University Press, I 998), 304-08, 344-47. For a review of some of the philosophical literature, see A. Preus, "Aristotle on Slavery: Recent Reactions," Philosophical Inquiry I 5 (I993): 33-47.

${ }^{2}$ B. Williams, Shame and Necessity (Berkeley: University of California Press, I993), I I 5, I I I.

${ }^{3}$ ENVIII. I I: I I6Ia32-bIo; cf. EE VII.9: I24 IbI3-24, VII. Iо: I242a28-3I.

${ }^{4}$ ENVIII. Iо: I I6ob27-32, VIII.II: I I6Ia32-35.

* Thornton C. Lockwood, Jr. is a Post Doctoral Fellow in the Philosophy Department at Fordham University.

Journal of the History of Philosophy, vol. 45, no. 2 (2007) 207-2 I 
rule of a master" (Pol. I.I: I 252a7-9). Aristotle rejects the Socratic notion of a unitary science of ruling in Politics I, on the basis of the difference in kind between ruling a free man and ruling a slave, ${ }^{5}$ but in the process of making his argument, he asserts not only that the relationship of master and slave is just, but also that it is beneficial to each. ${ }^{6}$ Whereas the ethical treatises deny any common benefit between a master and slave, the Politics unambiguously asserts that master and slave have the same benefit. ${ }^{7}$

A careful examination of Aristotle's arguments in the Ethics and Politics turns up a surprising distinction which, I will argue, allows him to evade the charge of internal inconsistency on the question of whether slavery is beneficial to a natural slave. Aristotle distinguishes, on the one hand, between a "common" benefit that can belong to two separate persons, and, on the other hand, the "same" benefit which exists between master and slave since they are, strictly speaking, one person in two bodies. Once one understands Aristotle's distinction, arguably, there is no explicit contradiction between the accounts in the Ethics and Politics. Nonetheless, when one steps away form the text and ponders the viability of distinguishing between a "common" and "same" benefit between two humans, problems remain. In the first section of this paper, I examine the passages which have led commentators to believe that Aristotle contradicts himself on the question of the benefit which exists between master and slave. In the second section, I show how Aristotle's distinction between two different kinds of benefit is a potential solution to the claim that the Politics and the Ethics contradict one another on this issue. Finally, in the third section, I conclude by considering why Aristotle endorsed slavery rather than hired labor.

\section{THE A P PARENT INCONSISTENGY OF EN VIII.9-I $/ E E$ VII.9-IO A N POLITICS I.4-6}

Let me begin by examining Aristotle's remarks about the $\sigma v \mu \phi \dot{\epsilon} \rho o \nu$, or "benefit," which exists between a master and slave in the ethical treatises. The Nicomachean and Eudemian Ethics provide parallel texts which, although different and compli-

${ }_{5}$ Pol. I.7: I 25 5bI 6-20; cf. I.I: I 252 a7-I 6, I.3: I 253 bI 8-23, and I.5: I 254 b2-6. See M. Schofield, "Ideology and Philosophy in Aristotle's Theory of Slavery" ["Ideology and Philosophy"], in his Saving the City (New York: Routledge, I 999), I 28-32; and M. Deslauriers, "The Argument of Aristotle's Politics I" ["Argument"], Phoenix 60 (2006): 48-69. For the Socratic "science of ruling" being criticized, see Plato, Statesman, 258e-59d; Xenophon, Memorabilia, III.4, I 2; III.6, I 2; Oikonomikos, XIII.5, XXI.Io; and Deslauriers, "Argument," 55-59. For the significance of Aristotle's argument against the Socratic position, see E. Garver, "Aristotle and the Will to Power: Character and Reason in Slavery and Freedom," Philosophy and the Contemporary World $\mathrm{I}_{3}$ (2006): 74-83.

${ }^{6}$ Pol. I.5.I 25 5aI-3; cf. I. 5: I 254 aI 6-20, 24, I 254 bio-I3, bi 6-20, I.6: I 25 5b6-9.

7 Pol. I.6: I255bI2-I 5. For a detailed list of the internal inconsistencies which commentators have found in Aristotle's treatment of slavery, see N. Smith, "Aristotle's Theory of Natural Slavery" ["Aristotle's Theory"] in A Companion to Aristotle's Politics, ed. D. Keyt and F. D. Miller (Oxford and Cambridge, MA: Basil Blackwell, I99I), I43-46.

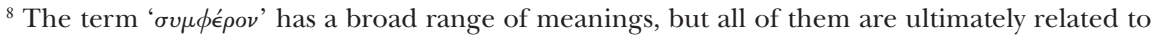
what is good or beneficial. The term's meaning can range from "the expedient" (e.g., the military or trade policies of a polis [ENVIII.4:I I 57a27-28, Rh. I.3:I358b2 I-25]) to the notion of "the common

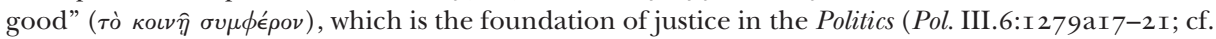
EN VIII.9:I I60aI I-I4). Etymologically, the word derives from the verb " $\sigma v \mu \phi \epsilon^{\prime} \rho \omega$ ', which means "to bring together," "to contribute," "to bear jointly." 
mentary, nonetheless both unequivocally deny that master and slave have something in common, and thus justice and friendship in their relations. The passages occur in EN VIII.9-I 2 (and the briefer, parallel discussion in EE VII.9-IO), and the immediate context is Aristotle's inquiry into the relationship between justice and friendship in relationships within the household (oikía), and their likenesses in the different kinds of regime-types $(\pi \circ \lambda \iota \tau \epsilon \hat{\imath} a \iota) .{ }^{9}$ The basis of the discussion is Aristotle's claim that

It seems likely, just as was said at the outset, that friendship and justice would seem to be about the same things and to be found in the same people. For in every associa-

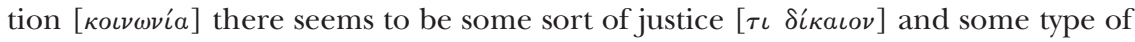
friendship also. (ENVIII.9:I I 59b25-27)

As Michael Pakaluk glosses the passage, Aristotle seems to be asserting that "friendship, justice, and association [ three things "vary together in degree" and "vary together in form." " For example, Aristotle will say that justice and friendship in the relationship between a father and a son is analogous in form and degree to that which exists between a royal ruler and a subject. Similarly, in other "right relations," justice and friendship between a husband and a wife are analogous to those between aristocrats, and justice and friendship between brothers are analogous to those between fellow citizens in a timocracy or a republic. But the analysis also holds in "deviant" or unjust relationships: since tyranny is the deviation from royal rule, then the form and degree of justice and friendship in a tyranny are similar or analogous to those which exist between a master and a slave. The husband/wife relationship which deviates from the aristocratic model is oligarchic, and the sibling relationship which deviates from the timocratic model is democratic. ${ }^{\text {II }}$

It is here that we find Aristotle's only extended discussion of slavery in the ethical treatises: since relationships within the household provide a "model" ( $\pi \alpha \rho a ́ \delta \epsilon \iota \gamma \mu \alpha)$ for relationships in the city, Aristotle explains the "deviant" relationship between father and son on the basis of despotic or tyrannical rule in a regime. He writes:

The association [ $\left.\kappa o \iota v \omega v^{\prime} a\right]$ of a father and his sons has the form of royal-rule, since the father is concerned for his children. ... Among the Persians, however, the father's rule is tyrannical, since he treats his sons as slaves. The rule of a master over his slaves

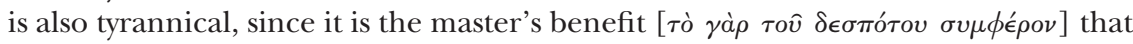
is achieved in it. (ENVIII.IO:I I6Ob24-25, 27-30)

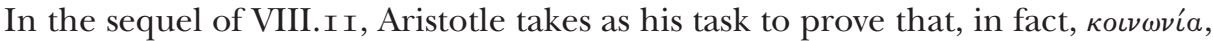
justice, and friendship vary as he had set out in ENVIII.9; and he does so in part by articulating the precise nature of friendship in each relationship. After having specified how friendship exists between father and son, between husband and wife, and between brothers, he turns to the "deviant" relationships and says:

9 See my article, "Justice in Aristotle's Household and City," Polis 20 (2003): I-2 I; and Nagle, Household, I77-202.

ro M. Pakaluk, Aristotle Nicomachean Ethics Books VIII and IX (Oxford: Oxford University Press, I998), I I I-I 2.

${ }^{11}$ EN VIII. Iо:I I 6ob23-6ra9; cf. EE VII.9:I 24 I b24-32. 
In the deviations, however, justice is found only to a slight degree; and hence the same is true of friendship. There is least of it in the worst deviation; for in a tyranny there is little or no friendship. For where ruler and ruled have nothing in common, they have no friendship, since they have no justice either, as, for example, in the case of a craftsman in relationship to a tool, a soul in relationship to a body, and a master in relationship to a slave. For in all these cases it is the user who is benefited [ $\dot{\omega} \phi \epsilon \lambda \epsilon \hat{\imath} \tau a \iota]$, but there is neither justice nor friendship toward inanimate things. Nor is there any toward a horse or cow, or toward a slave, insofar as he is a slave. For master and slave

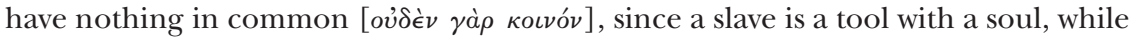
a tool is a slave without a soul. (ENVIII.I I:II6IazO-b5)

Aristotle has more to say, but let me pause for the moment, in order to underscore the main thrust of this passage.

In his analysis of relations in the household and the city, Aristotle had established that associations are relationships in which two or more people have something in common, and that all such relationships exhibit patterns of justice and friendship. But since association, justice, and friendship vary together in degree and form, in a relationship between two people in which nothing is in common, there is no "association," nor is there justice or friendship (or, at least, none which is significant-a point to which I will turn at the end of section 2 below). Thus, since the master and slave have nothing in common, it follows that their relationship is not an association, and as such, it lacks both friendship and justice. It appears that slavery in the household is nothing more than a sort of Persian despotism in which the ruler exploits the ruled for the sake of the ruler's benefit. Therefore, it would appear that, according to the Nicomachean Ethics, the relationship between a master and a slave is an exploitative one which benefits only the master.

As numerous commentators have pointed out, such a characterization of the relationship between master and slave seems irreconcilable with the account of slavery in the first book of the Politics, which explicitly argues that slavery is beneficial for both master and slave. ${ }^{\mathrm{I2}}$ Although the extended argument of Politics I-which concerns not just slavery, but also the refutation of a Socratic unitary science of rule, and the basis for the accumulation of property within the household-is too complicated to contextualize briefly, ${ }^{\mathrm{I}}$ the conclusion which contradicts the claim of the Ethics can be excised without too much distortion. Briefly, Aristotle examines the question of what sorts of property and tools are necessary for the household, and concludes that a slave is a living piece of property ( $\kappa \tau \hat{\eta} \mu a ́$

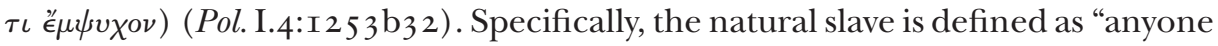

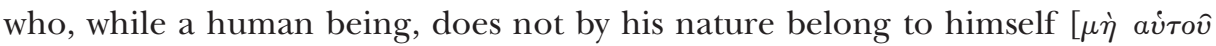

${ }^{12}$ See Price, Love and Friendship in Aristotle and Plato [Love and Friendship] (Oxford: Clarendon, I 989), I76-78; C. C. W. Taylor, "Politics," in The Cambridge Companion to Aristotle, ed. J. Barnes (Cambridge: Cambridge University Press, I 995), 254-57; P. Garnsey, Ideas of Slavery from Aristotle to Augustine [Ideas of Slavery] (Cambridge: Cambridge University Press, I996), I24-26; P. A. Brunt, "Aristotle and Slavery," in his Studies in Greek History and Thought (Oxford: Oxford University Press, I999), 366-7I; M. Schofield, "Appendix 2: Slaves and Friendship," in his Saving the City, I37-40; M. Harvey, "Deliberation and Natural Slavery" ["Deliberation"], Social Theory and Practice 27 (200I): 54-57; R. Kraut, Aristotle Political Philosophy [Aristotle] (New York: Oxford University Press, 2002), 295-30I.

${ }^{13}$ For the argumentative structure of Politics I, see Schofield, "Ideology and Philosophy," I 28-3 I; C. Natali, "La struttura unitaria del libro I della 'Politica' di Aristotele," Polis 3 (I979/80): 2-I8; and Deslauriers, "Argument," 48-52. 
$\phi \dot{v} \sigma \epsilon \iota]$ but to another is by nature a slave" (Pol. I.4:I254aI4-I 5). Infamously, Aristotle continues in the subsequent chapter to decide whether or not such a natural slave exists, and if he does, whether such slavery is better and just for him (I254aI7-I9). ${ }^{14}$ To cut to the chase, let me quote Aristotle's conclusion, which comes at the end of Politics I.6:

So it clear that the dispute about slavery has some reason behind it and that some slaves are both by nature slaves and some free are not by nature free. It is also clear that in other cases a natural distinction does obtain, where it is beneficial $\left[\sigma v \mu \phi \epsilon^{\prime} \rho \in \iota\right]$ and just for the one to be a slave and the other a master. Here the first should be ruled by the second with the rule for which the second is naturally fitted, namely mastery. But if mastery is exercised badly, it is not beneficial to either of them, for part and whole,

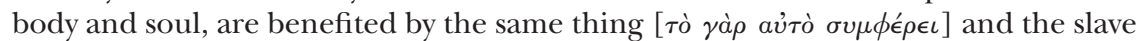
is a part of his master as a sort of living but separate part of his body. Consequently,

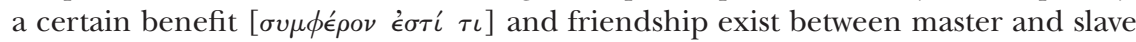
when they deserve by nature to be master and slave. (Pol I.6: I 25 5b4-I 4)

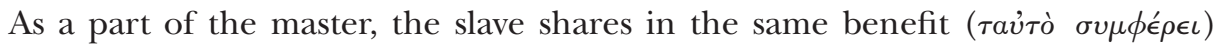
which the master receives (I255b9-IO, I252a35); but further, such a benefit is even the grounds for a kind of friendship between master and slave. Although the Politics never contradicts the Ethics concerning whether or not the master and

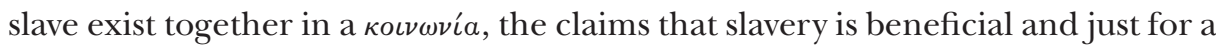
natural slave, and that there exists a kind of friendship between master and slave based on such an identical benefit, are in direct opposition to the discussion in the ethical treatises.

As noted above, commentators have often taken Aristotle to task for this major inconsistency in his account of slavery. Some, such as Williams and Brunt, think that Aristotle was simply in the grip of an ideologically or historically inescapable worldview which forced him to make contradictory assertions. ${ }^{15}$ Others, such as Garnsey and Schofield, have taken a developmental approach to the problem, and suggested that Aristotle's inconsistency on the question can be resolved by attributing the different texts to different times of composition. ${ }^{16}$ Somewhat more ambitiously, others, such as Ambler and Nichols, have suggested that the contradictions in Aristotle account of slavery are intended, and that they indicate an esoteric critique of slavery as it was practiced in Aristotle's time. ${ }^{17}$ Although different commentators have arrived at different solutions to the contradiction, so far as I can tell, all are agreed that Aristotle's texts are irreconcilable, insofar as they, at one and the same time, assert that slavery is and is not beneficial to the

${ }^{14}$ For a recent summary of the debate concerning natural slavery in the Politics, see Tony Burns, "The Tragedy of Slavery: Aristotle's Rhetoric and the History of the Concept of Natural Law," History of Political Thought 24 (2003): I6-36, at I 8-28.

${ }^{15}$ See Williams, Shame and Necessity, I I 5-I 6; Brunt, "Aristotle and Slavery," 344-45, 367-68. Cf. E. Wood and N. Wood, Class Ideology and Ancient Political Theory [Class Ideology] (New York: Oxford University Press, I978), 230-33.

${ }^{16}$ See Garnsey, Ideas of Slavery, I 25-27; Schofield, "Slavery and Friendship," I 37-40. Cf. J. Rist, The Mind of Aristotle (Toronto: University of Toronto Press, I989), I 54-57.

${ }^{17}$ See W. Ambler, "Aristotle on Nature and Politics: The Case of Slavery," Political Theory I 5 ( I987), 405-07; M. Nichols, "The Good Life, Slavery, and Acquisition: Aristotle's Introduction to Politics," Interpretation I I (I983), I73-76. Cf. M. Davis, The Politics of Philosophy (Lanham, MD: Rowman and Littlefield, I996), I 5-32. 
slave.$^{18} \mathrm{I}$ propose that, in fact, Aristotle's claims about whether slavery is beneficial are consistent, if one understands the distinction between the "common benefit" shared by two people and the "same benefit" shared by a whole and its parts.

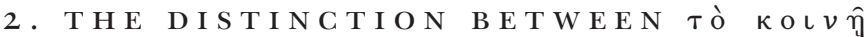

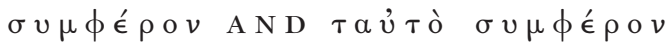

I contend that Aristotle distinguishes between a "common benefit," which presupposes at least two separate persons who share some goal in common, and "the same benefit," which exists between a part and the whole of which it is a part. In this section, I simply want to present evidence to prove that Aristotle makes use of this distinction and to look at some passages which might seem to undercut the distinction. The question of whether or not the distinction which Aristotle makes is a viable one is something I leave for section 3 below. Let me begin by noting that I can find no instance in the Aristotelian corpus (notwithstanding the apparent exceptions I examine below) in which Aristotle asserts that a master and slave

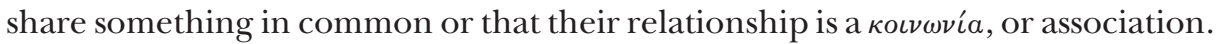
Rather, Aristotle consistently maintains that the slave is a part of the master. Thus, there is no injustice towards a slave, because one cannot wrong oneself, and a slave

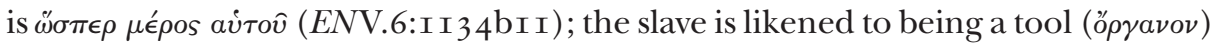
or member ( $\mu$ ópıov) of the master (EN VIII:I I.I I6Ia34, EE VII.9:I24 Ib23, Pol. I.4:I 254a9-II, aI7); the slave is related to the master as body is related to soul, namely, as that which rules is related to that which is ruled (ENVIII.II:I I6Ia35,

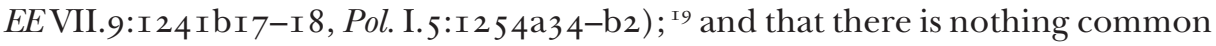

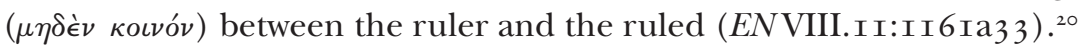

There are two interesting passages which appear to undermine my claim that Aristotle unequivocally denies that there is anything in common between master and slave. In Politics I. I 3, Aristotle's claim that a slave must possess a minimum of virtue in order to fulfill his or her tasks sparks a new question: must not also artisans ( $\tau \epsilon \chi \nu i \tau a \iota)$ possess virtue, since they too can do their work poorly? Aristotle claims:

\footnotetext{
${ }^{18}$ Price (Love and Friendship, I77-78) resolves the inconsistency by suggesting that Aristotle ultimately has two aspects of the natural slave in mind-using Aristotle's terminology, slave qua slave, and slave qua human (I I 6 I b5-6) - and so resolves the inconsistency through the distinction within the same person. Barker long ago pointed out that such a "distinction is impossible," and thus, that Aristotle's theory is "refuted by its own author in the course of its statement" (E. Barker, The Political Thought of Plato and Aristotle [New York: Dover, I959], 366, 367). When the present article was accepted for publication in June, 2004, I was unaware of any authors who thought these texts reconcilable. Nagle, Household, and P. Simpson, "Aristotle's Defensible Defense of Slavery" ["Defense"], Polis 23 (2006): 95-I I 5, subsequently drew upon my unpublished manuscript and endorsed its thesis.

${ }^{19}$ Some authors, such as W. W. Fortenbaugh, have argued that the relationship between master and slave is modeled better by the relationship between the rational and the desiring parts of the soul (see Pol. I. 5.I 254 b5-6, and W. W. Fortenbaugh, "Aristotle on Slaves and Woman," in Articles on Aristotle 2: Ethics and Politics, ed. J. Barnes, M. Schofield, and R. Sorabji [London: Duckworth, I977], I35-9). But as Smith points out, Aristotle seems to think that the reason/desire model is more appropriate for the male/female relationship (see Pol. I.5.I254bI3-I6, I.I 2.I 259bI-4, I.I3.I 260a7-I4, and Smith, "Aristotle's Theory," I 46; see also M. Deslauriers, "Aristotle on the Virtues of Slaves and Women" ["Virtues"], Oxford Studies in Ancient Philosophy 25 [2003]: 2 I3-3 I, at 22 I-29).

${ }^{20}$ Deslauriers ("Virtues," 2I6) suggests that "natural subjects . . . acquire virtue by borrowing the phronesis of a natural ruler." Such a position reinforces my claim that the slave and master are two parts of one whole.
} 


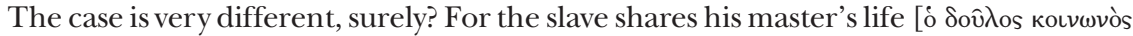
$\zeta \omega \hat{\eta} s]$, but the artisan is more remote and has as much of virtue as he has of slavery

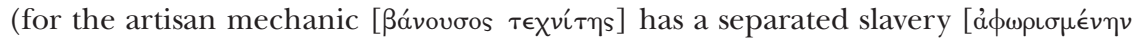

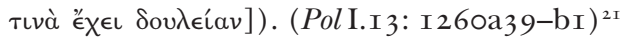

Banausic artisans, in other words, are only "temporary slaves" when they are actually employed, and thus, as Peter Simpson points out, they "are worse and lower than slaves, and only rise to the level of slavery, and of slavish virtue, when actually employed by someone."22 In this instance, when Aristotle asserts that the slave has

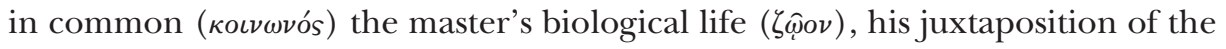
natural slave with such "temporary slaves," or day-laborers, suggests that the master and slave exist in a symbiotic unity unlike any sort of modern employee/employer relationship. Indeed, Aristotle's assertion that the slave shares in a master's life

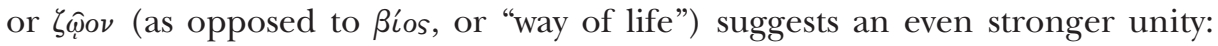
whereas, say, an itinerant worker, employed only during harvest time, shares in and contributes to a farmer's bottom line, the natural slave is not someone hired or fired, as suits the employer, but almost an extension of the master, much like a wet nurse is the extension of a mother. ${ }^{23}$ In any case, although Aristotle in this passage does suggest that master and slave "have something in common," that thing in common is not just some good or goal internal to their relationship; rather, it is their symbiotic unity.

The second passage which appears to contradict my claim that master and slave have nothing in common is located in Pol. I.5. Aristotle claims that:

For in everything that is fashioned into a common unity [є̌v $\tau \iota$ кoเvóv], whether the parts be continuous and discrete, a ruling and a ruled part are apparent, and this inheres in living things from the whole of nature. (I 254a28-32)

In the examples that follow, body and soul, or intellect and desire, are "continuous" ( $\sigma v \nu \in \chi o ́ v)$ common unities, whereas man and woman, or human and domesticated

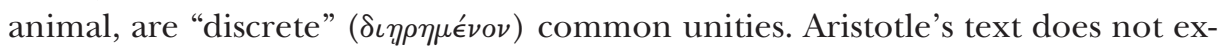
plicitly specify whether master and slave form a continuous or discrete unity, but the evidence I have furnished above suggests that master and slave are a "continuous unity," rather than a discrete one. But in either case, the point is the same: although Aristotle does claim that a master and slave have something in common

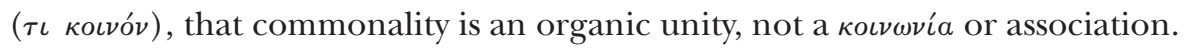

I have emphasized that master and slave have nothing in common because Ar-

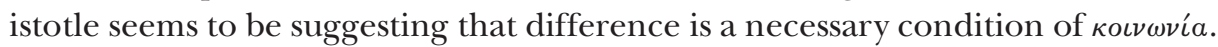

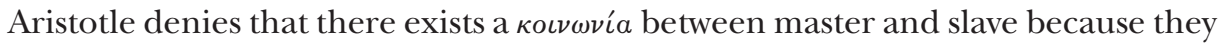
are inseparable as persons or selves. Let me cite an extended passage from the Eudemian Ethics which most clearly articulates the point:

All constitutions $\left[\pi \circ \lambda_{\iota \tau \epsilon \hat{\imath} a \iota}\right]$ are some form of what is just, for they are associations

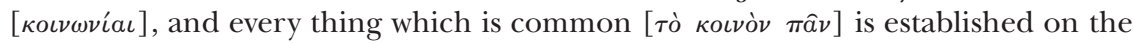

${ }^{21}$ I 260a39-6obi, P. Simpson, trans., The Politics of Aristotle (Chapel Hill, NC: University of North Carolina Press, I997).

${ }^{22}$ P. Simpson, A Philosophical Commentary on the Politics of Aristotle (Chapel Hill, NC: University of North Carolina Press, I998), 69.

${ }^{23}$ For the distinction between $\beta i$ ios and $\zeta \omega \hat{\omega} o \nu$, see D. Keyt, "The Meaning of BIOS in Aristotle's Ethics and Politics," Ancient Philosophy 9 (I989): I 5-2I. 
basis of that which is just.... But there is no association of those things, namely those which are similar [ $\left.\dot{\delta} \mu o^{\prime} \omega s\right]$ like soul in its relation to body, the craftsman in relation to his tool, and the master in relation to his slave. For in these cases there is no "two," but the former is one, and the latter is not one, but a part of the former. ${ }^{24}$ Nor is the good divisible between each of them, but rather the good of both belongs to the one for whose sake they exist. (EE VII.9:I 24IbI3-I 5, I7-22)

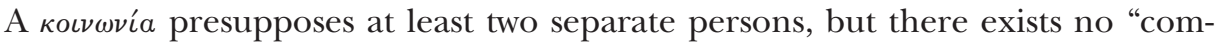
mon" good between master and slave because, ultimately, they are inseparable. Although two separate people can seek some common project, there is no "common" goal between my right and my left hands working in unison. The rest of Aristotle's claims seem to follow from that insight: without a "common" project

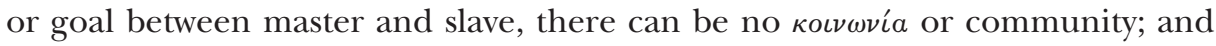
community would seem to be a necessary condition of justice and friendship between two people. ${ }^{25}$

Paradoxically, Aristotle's denial of any common benefit between master and slave in the ethical treatises supports his claim in the Politics that natural slavery is beneficial. As noted above, although commentators have found the two claims inconsistent, what Aristotle actually says in the Politics is more subtle: throughout, he consistently maintains that the interest between master and slave is the same ( $\tau a v ่ \tau o ̀ ~ \sigma v \mu \phi \epsilon ́ \rho \epsilon \iota)$, and he does so on the grounds that "the same thing is beneficial for both part and whole, body and soul, and a slave is some part of a master, a sort of living but separate part of his body." ${ }^{26}$ Aristotle distinguishes between the case of a "common benefit," which is shared by two separate individuals, and the "same benefit," which is shared by any whole and one of its parts. Because Tom and Harry are two separate people, they do not have the same interest, but rather a common interest; and because my hand is a part of my body, it does not have an interest or benefit common to it and the rest of me, but rather the interest of my hand is the same as the rest of me. Thus, it is perfectly consistent for Aristotle to deny that master and slave have any common benefit, while, at the same time, to assert that they possess the same benefit.

There is one last, interesting problem text which some authors have understood to deny Aristotle's claim that slavery is beneficial for both master and slave. In Politics III.6, in the midst of his extended examination of the common good, Aristotle writes that

[t] he despotic rule of a master (although in truth the natural slave and natural master

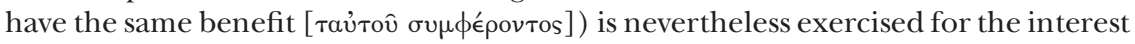

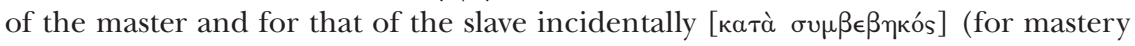
cannot be preserved if the slave is destroyed). (I $278 \mathrm{~b} 33-36)$

Many have taken Aristotle's assertion to be inconsistent with his account of slavery in Politics I, and indeed, even a sly recognition on Aristotle's part that what was

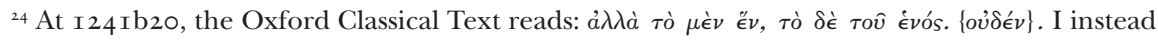

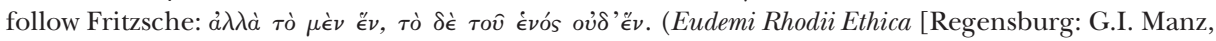
$\mathrm{I} 85 \mathrm{I}])$.

${ }^{25}$ Necessary but not sufficient: the schema of household relations and regimes suggests that, in

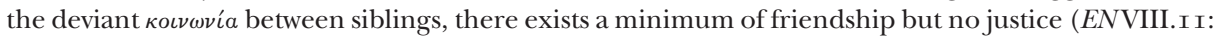
I I6Ib9-II).

${ }^{26}$ Pol. I.6:I 25 5b9-I 5; I.2:I $252 \mathrm{a} 30-34$; cf. I. $5:$ I 255 aI-3. 
said earlier in the work about natural slavery was not the whole story, since here he is granting that the benefit only "accidentally," or coincidently, accrues to the

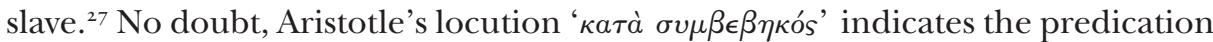
of an inessential, rather than an essential or necessary, quality or characteristic. ${ }^{28}$ But 'accidental' does not mean "non-existent." In the subsequent text, Aristotle says that a pilot of a ship captains the vessel for the benefit of the crew, and only "accidentally" in his own interest, but that hardly means that a Greek pilot braves the storms and pirates of the Aegean out of selfless altruism. Rather, the pilot qua sailor on the ship directly participates in, and obviously is motivated by, the benefit which he qua pilot aims at for the good of all on the ship (I279a4-7). Although master and slave take part in the same benefit, the relationship is not intentionally a paternalistic one in which the master exercises control only for the betterment of the slave. ${ }^{29}$ But just because mastery is not paternalistic selflessness, it does not follow that it is wholly selfish exploitation. Unlike, say, the day laborer noted above, the slave enjoys the stability and inclusion within an oikia which allowed for his or her betterment. In a world in which exclusion from an oiкia was a form of migrant "homelessness," participating in such goods even incidentally was better than the alternatives..$^{\circ}$

Before turning to the question of the viability of Aristotle's distinction, one last word needs to be said about whether or not the master and slave experience friendship towards one another. As noted above, the Politics unambiguously asserts that, since master and slave have the same benefit, there is friendship between them, whereas the Ethics asserts that qua slave, such friendship is impossible. ${ }^{3 \mathrm{I}} \mathrm{I}$ suspect that Aristotle did perceive some tension between the two claims, regardless of his distinction between a common and same benefit, since both the Eudemian and Nicomachean Ethics postulate a qualified friendship between master and slave. In the case of the Eudemian Ethics, Aristotle claims that, although there is no jus-

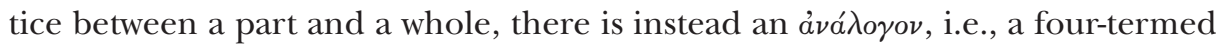
proportion like, just as health is the proper relationship between body and soul, so too friendship is the analogous relationship between slave and master. ${ }^{32}$ The claim is slightly more enigmatic in the Nicomachean Ethics. Aristotle writes:

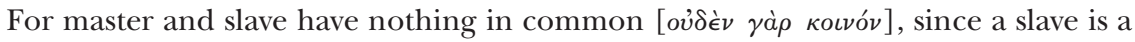
living tool, just as a tool is an inanimate slave. Therefore, there can be no friendship

${ }^{27}$ See, for instance, Brunt, "Aristotle and Slavery," 369-70; Smith, "Aristotle's Theory," I 46.

${ }^{28}$ See Metaph. V.30:I025aI4-30, VI.2:I026b28-27a8.

${ }_{29}$ Cf. Schofield, "Ideology and Philosophy," I 27-28; Kraut, Aristotle, 298-99.

$3^{\circ}$ Consider for a moment the plight of a $5^{\text {th }}$ - or $4^{\text {th }}$-century Athenian slave. If the slave is Greek, then most likely the slave's city of origin had been sacked, the adult males of the family have been slaughtered, and the women and children of the family sold into bondage. If the slave is not Greek, then in addition to the separation from family and home, such a person lives in a foreign world, is unable to speak the language, and is ignorant of the most basic Athenian customs-customs, of course, which were not readily "publicized" beyond Athens except through legend. In either case, the person would have been denied the legal right of marriage or the parental right to off-spring. See further V. J. Rosivach, "Enslaving Barbaroi and the Athenian Ideology of Slavery," Historia 48 ( I999): I 29-57; and Brunt, "Aristotle and Slavery," 379-80.

${ }^{31}$ Pol. I.6: I 25 5bi 2-I 4; EN VIII. Iо: I I 6rb5-6.

${ }^{32}$ EE VII.IO: I 242a29-32. Possibly what Aristotle has in mind is the "metaphorical" problem of justly relating the different parts of the soul. See $E N$ V.I I: I I38b5-I4. 
with a slave qua slave, though there can be qua human being. For there seems to be some room for justice in the relations of every human being with every other that is

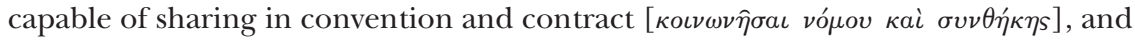
hence friendship is also possible, in so far as one is human. ${ }^{33}$

This passage is confusing because Aristotle first asserts that master and slave have nothing in common and then implies that they share a commonality, namely, that both have an amount of rationality sufficient to enter into convention (vóros) ${ }^{34}$ and contracts, because both are human. Perhaps some minimum rationality is

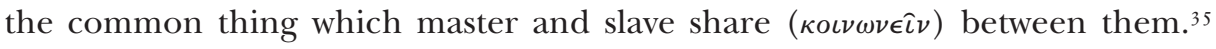
The problem is that such a bare minimum of rationality is insufficient for being an Aristotelian ethical agent, and so, one presumes, a friend. ${ }^{36}$ As Aristotle reminds us, neither children not slaves possess $\pi \rho \circ \iota^{\prime} \rho \epsilon \iota s$, or choice, but friendship ( $\phi \iota \lambda \iota a)$ - as opposed to mere "liking" ( $\left.\phi^{\prime} \lambda \eta \sigma \iota s\right)$-seems to require such a degree of mature agency. ${ }^{37}$ Perhaps friendship of a slave is more like that which is felt for an inanimate object, which although likable, is incapable of a return of affection..$^{8}$

\section{IS ARISTOTLE'S DISTINCTION LOGIGALLY VIABLE?}

I have argued that Aristotle's denial of any common benefit between master and slave is consistent with his assertion that natural slavery is beneficial, on the basis of the claim that Aristotle distinguishes between a "common benefit," which presupposes two separate individuals, and the "same benefit," which can exist between a whole and its parts. One might grant my textual evidence, acknowledge that Aristotle does, in fact, seem to be drawing such a distinction, and yet insist that

${ }_{33}$ ENVIII. I I: I I 6I b3-8, Rackham translation adapted, Aristotle, Nicomachean Ethics, (Cambridge, MA: Harvard University Press, I990). For such philanthropy or friendship to other humans qua human, see EN VIII.I: I I 5 aI 6-22; but cf. Pol. II.2: I 263 bi 5-28.

${ }^{34}$ Nussbaum suggests that, since Aristotle mentions vónos in this passage, he may have the conventional, rather than the natural, slave in mind. See her "Shame, Separateness, and Political Unity: Aristotle's Criticisms of Plato," in Essays on Aristotle's Ethics, ed. A. O. Rorty (Berkeley: University of California Press, I980), 434 n. 54.

35 The extent to which a natural slave is rational or capable of following instruction is a difficult problem, but ultimately one that is independent of the question of whether master and slave share the same or a common benefit. For surveys of the topic, see Kraut, Aristotle, 283-90; and Deslauriers, "Virtues," 2I3-3 I. Cf. Pol. I. 5: I254b23-24; I. I3: I259b28-29, I 260 I I-I4.

${ }^{36}$ As Harvey ("Deliberation and Natural Slavery," 62-64) points out, the key difference between modern and Aristotelian notions of moral agency is that modern liberalism-premised on the claim that all men are equal- "deflated" the standard of moral personhood to a bare minimum of deliberative ability to which all humans could aspire; Aristotelian "moral personhood" presupposes a deliberative excellence obtainable by a small few. Thus, for example, one finds Hobbes rejecting Aristotle's natural slavery in the Leviathan because

\footnotetext{
[t] he question 'who is the better man?' has no place in the condition of mere nature, where ... all men are equal. The inequality that now is, has been introduced by the laws civil. . . . For there are very few so foolish that had not rather govern themselves than be governed by others; nor when the wise in their own conceit contend by force with them who distrust their own wisdom, do they always, or often, or almost at any time, get the victory. (Hobbes, Leviathan, ed. E. Curley [Indianapolis: Hackett, I994], ch. xv, par. 2I)
}

${ }^{37}$ EN III.2:I I I Ib6-IO; VIII.5: I I 57b29-32; VIII.I3: II63a2 I-23. On the presuppositions of Aristotle's notion of mature ethical agency, see further my "Ethical Justice and Political Justice," Phronesis 5I (2006): 29-48.

${ }^{38}$ EN VIII.2: I I 5 5b26-34; cf. VIII.5: I I $57 \mathrm{~b} 25$. 
the distinction is a hollow one with no real difference. I wish to consider such a response through the examination of two other relationships which seem similar to the relationship between master and slave, namely, those which obtain between father and child, and between employer and employee. If there is no difference between these relationships with respect to the same or common benefit, then the distinction may be a questionable one.

The father/child relationship is a good place to start, because Aristotle himself draws an important similarity between children and slaves. According to ENV.6, one cannot commit injustice against one's own child for the same reason that one cannot wrong a slave: until the child is of an age when he can be "separated" ( $\chi \omega \rho \iota \sigma \theta \hat{\eta})$ from his father, he too is like "a part of [the father's] self, and no one intentionally chooses to harm one self” ( I I 34bIo-I 2). Indeed, elsewhere Aristotle characterizes a child as "something of his parents' selves" [ $\dot{\omega} s \dot{\epsilon} a v \tau \hat{\omega} \nu \tau \iota]$ (I I6IbI8) and leaves no doubt that,"until a certain age," the child is intimately a part of his parents. ${ }^{39} \mathrm{At}$ the same time, Aristotle's notion of "father" is hardly a Roman paterfamilias-i.e., one who possessed the power of life or death over all within his household, even after he had attained his majority ${ }^{40}$-and, in ENVIII.9-I 2, he explicitly claims that

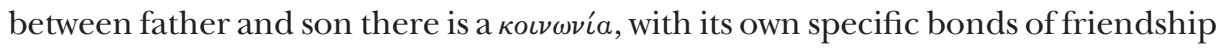
and claims of justice. Most likely, although a male child is always his father's son, with time, he also become his own man-his own self, an $\dot{\epsilon}^{\prime} \lambda \epsilon \dot{v} \theta \epsilon \rho o s$ or free man, which the Metaphysics points out is "someone who exists for his own sake [o aivov

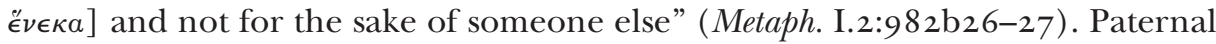

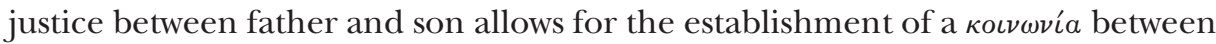
what began as a whole and a part, but what subsequently becomes two independent persons. But such a claim seems impossible for the master and slave. By definition

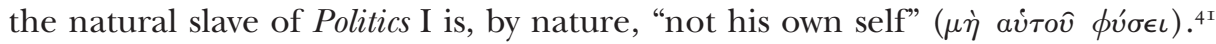
Although there are passages where Aristotle holds out the freedom of slaves as a desideratum, his discussion of "despotic justice" in the Politics seems irreconcilable with the notion that a slave over time could gradually become separate and free from his master..$^{42}$ Although children are not their parents' equals, sons are

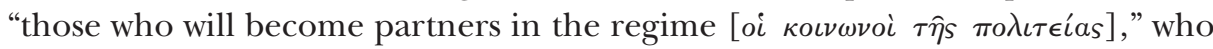
need to be ruled "as freemen," or the exact opposite of slave. ${ }^{43}$

${ }^{39}$ For the notion of an "other self," see Price, Love and Friendship, I65. For such transitions, see D. Tress, "Aristotle's Child: Development Through Genesis, Oikos, and Polis," Ancient Philosophy I7 (I997): 63-84.

$4^{\circ}$ Dionysius of Halicarnassus, Roman Antiquities, trans. E. Cary (Cambridge, MA: Harvard University Press, I937), II.26-7.

${ }^{41}$ Pol. I.4:I254aI4-I 5; cf. I.5; I254b2I.

${ }^{42}$ Pol. I.I 3: I $260 a 39-b 7 ;$ cf. Oec. I. 5: I 344b5-22; Pol. VII. Io: I $330 a 3$ I-32. See Smith, "Aristotle's Theory," I 53-54. Kraut (Aristotle, 297-98) has argued that over time, under proper supervision, the natural slave would be able to develop a minimum of virtue and be capable of freedom. In general, Kraut's position elevates the rationality of the natural slave and lowers the standard necessary for being free. Such a position also seems to undercut the distinction between despotic and paternal rule, even though Kraut (ibid., 298-99) tries to avoid construing the master and slave relationship as paternalistic. Cf. J. Frank, A Democracy of Distinction (Chicago: University of Chicago Press, 2005), 26-45; and Ober, Political Dissent, 345-46.

${ }_{43}$ Pol. I.I3: I26obi9-20; I.I2: I259a39-b4; EN VIII. I2: I I6IaI8-20; Pol. I.4: I254aI-I7; I.6: I 255 b9-I 5 . 
Aristotle's characterization of the relationship between father and child entails that the natural slave's status as a "part" of the master is only a necessary condition of having the same benefit (rather than a common benefit) with the master. A child is part of his father, according to Aristotle, but the father and child share a benefit in common. Such a common benefit is an asymmetrical one: Aristotle notes that, whereas a father bestows upon a child such gifts as existence, nurture, and education, the child can never equally reciprocate, and, like a disciple to his teacher, can only return that which is possible rather than that which is owed..$^{44}$ But since such a good is asymmetrical, it cannot be one and the same between father and son. In sum, the examination of the father/son relationship shows that the problem of a common benefit between master and slave turns neither on the issue of equality (since two unequals can share a common benefit), nor on the issue of being a "part" of another's self (since children are parents' other selves). To understand the difference between Aristotle's treatment of a son and a slave, we must look elsewhere.

Consider a second relationship: that between an employee and employer. Like many modern readers of Aristotle, Richard Kraut reasonably notes that, although one can grant that the best way of life requires leisure,

[t] his point would not by itself allow Aristotle to conclude that slavery is justified. For it could be objected that the benefits obtained through slavery are available in other ways. Rather than own slaves, one can hire workers to perform the same services. One of the questions we must ask is why Aristotle thinks that the benefits of slavery could not be equally well secured in some other way.45

According to Aristotle, the relationship between master and slave is one in which the benefit received is the same, but the employer/employee relationship is one of mutual but separate benefit. If there is no reason why Aristotle preferred natural slavery to hired labor, then his distinction between the two kinds of labor and the different benefits found in each may seem arbitrary or even ideological. Thus, to understand the distinction between free and unfree labor, it is helpful to ask why could Aristotle's master not simply hire a nanny, a housekeeper, and a gardener, in order to provide him with the leisure necessary for contemplation or political activity?

One possible response would be that the triumphs of ancient Greek society depended upon the economic exploitation of a slave class, and that it would have been economically impossible for a society both to be based in free labor and to provide an upper class with the sort of leisure that Aristotle clearly envisions as necessary for the best way of life. ${ }^{46}$ Put more bluntly: why pay for what you can get for free (or, at least, for no more than the cost of boarding your slaves)? Although, on the macroeconomic level, there is much debate about the extent to which Greek society was dependent upon slave labor, it is wrong to think that Aristotle's virtuous man used slaves to save a drachma here or there. ${ }^{47}$ Aristotle not only in-

${ }^{44}$ EN VIII.I I:I I 6Ia 5-I 7; VIII.I 2: I I 62a4-9; VIII.I 4:I I 63b 1 5-22; IX. I:I I 64b2-6.

${ }^{45}$ Kraut, Aristotle, 282.

${ }^{46}$ See, for instance, Brunt, "Aristotle and Slavery," 344-45, who advances this criticism.

${ }^{47}$ On the relationship between Greek society and its dependence on slavery, see most recently P. Cartledge, "Greek Civilization and Slavery," in Classics in Progress, ed. T. P. Wiseman (New York: Oxford 
sists that the virtuous man must possess significant external goods ( $о \rho \eta \gamma i a)$, but we know from the discussion of the virtue of magnificence $(\mu \epsilon \gamma a \lambda \circ \pi \rho \epsilon \epsilon \epsilon \iota a)$ in $E N$ IV.2 that such a man is able to make charitable expenditures on the scale of fitting out triremes for the navy, sponsoring the entire cast of a play, or giving banquets to the public. ${ }^{8}$ Although the possession of wealth does not make budgeting unnecessary, it would seem that Aristotle's virtuous man was financially able to hire servants, rather than simply make use of slaves. ${ }^{49}$ It is necessary to find another reason for Aristotle's preference for unfree labor over hired labor.

One might argue that Aristotle possessed a certain class prejudice that made money "dirty" and beneath either Aristotle or his virtuous man..$^{\circ}$ It might be claimed that the servants Aristotle has in mind-mostly domestic servants responsible for tasks such as child rearing, cooking one's meals, and taking care of the elderly-require a sort of loyalty or allegiance that cannot be obtained through wage labor. Thus, for the same reason that Aristotle finds it beneath a philosopher to associate with his student for a wage, one might argue that it would be beneath a master to have to hire natural slaves; they should simply gravitate towards him once they see the benefit he will provide them. ${ }^{51}$ Although it is true that the typical roles which Aristotle's natural slave would fulfill are those which intimately incorporated him or her into the master's oikía, Aristotle has no problems with the notion of associations modeled upon the mutual advantage found in the relationship between an employer and employee. Indeed, in his discussion of the different kinds of friendships, Aristotle is at pains to prove that a relationship of mutual advantage - what he classifies as a "utility friendship"-is, in fact, a friendship, albeit one which is likely more short-lived and prone to disagreements than

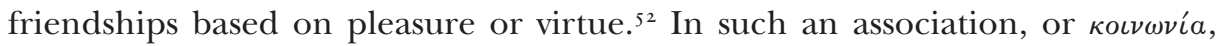
each individual enters into the relationship because each is useful to the other.

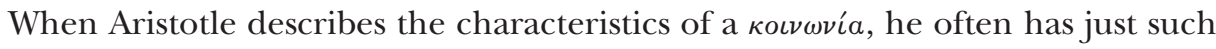
a relationship in mind: for instance, sailors working on a ship together to seek profits, or travelers traveling together for mutual protection. ${ }^{53}$ No doubt, there are associations which rise above mere mutual advantage- and Aristotle's criticisms of Lycophron's "social contract" theory of political association makes clear that the polis is not simply an association of mutual advantage (Pol. III.9: I 28ob8-I2) - but it does not follow that relationships which exist only for mutual advantage are in any way "tainted" for Aristotle.

Why can the relationship of master and slave not be accommodated by the "mutual advantage" model of relationship found between employee and employer? Kraut, for instance, argues that

University Press, 2002), 247-62. The question has a long history; see, for instance, M. I. Finley, "Was Greek Civilization Based on Slave Labor?” Historia 8 (I959): I45-64.

${ }^{48}$ ENI.ro:I Iorai 4-I6; IV.2:I I 22bi9-23; cf. X.8:I I 78a28-34.

${ }^{49}$ On the nature of possessions in Aristotle's household, see Nagle, Households, 3 I-75.

${ }^{5}$ See, for instance, Wood and Wood, Class Ideology, 230-37.

${ }^{51}$ For Aristotle's criticisms of making the relationship between student and teacher a paid one, see ENIX.I:I I 64a24-b6.

${ }^{52}$ EN VIII.3:I I 56aIo-22; IX.I:I I64a2-I3. Aristotle criticizes those who would deny that utility friendships are in fact forms of friendship simply because they do not rise to the standard of complete friendship (ENVIII.4:I I 57a25-36; EE VII.2:I 236a25-34).

${ }^{53}$ See EN VIII.9:I I 59b27-29, I I60aI 5-I 8; VIII.I 2:I I 6IbI3-I 5; Pol. III.6:I 279a4-8. 
[t]he slave benefits from slavery, then, because were he not a slave, he would lead a life of idleness, dissolution, and petty immorality. The supervision of a master (at any rate, a good master) will keep his worst qualities in check. Properly disciplined, he can acquire a small portion of virtue, and although his life can never be a good one, since real virtue is beyond his capacities, his subordination to a master make him less distant from this ideal than he would otherwise be. ${ }^{54}$

Is this virtue not a benefit which the slave receives which is his own and separate from the benefit which he brings to the master?

When Aristotle claims that the slave is a part of the master, or a living tool, he appears to be denying that such a human could derive a benefit that is separable from the benefit he shares with a master. Contrary to Kraut's argument above, the free or independent natural slave would not be an idle of a dissolute person who could benefit from a job; rather, such a natural slave would seem incapable of improvement independent of a natural master. As noted above, Aristotle was aware of day-laborers or hired artisans, but since he ranks the benefits they receive below that of a slave, he underscores that the distinction between "mutual advantage" relationships and relationships in which both parties have one and the same advantage. By analogy, consider what is better for the long-term maintenance of an automobile: that it be rented out to multiple casual users, or that it be possessed by a single conscientious owner. Aristotle seems to think that a natural slave hired as a wage laborer is like a rental car, which no one owns and for which no one cares, because when the rental period is through, the renter knows that the long-term care of the car is not his or her problem. In sum, Aristotle endorses slave over free labor at least in part because it appears to him to be the only way for a natural slave to accrue any consistent or regular benefit. ${ }^{55}$

Reflection upon Kraut's question-why could Aristotle not have endorsed wage labor rather than slave labor?-thus supports my claim that, not only does Aristotle distinguish between relationships which aim at a common benefit and those in which the benefit aimed at is the same, but also that this is, in fact, a viable distinction. In Aristotle's eyes, the relationship between an employer and employee is an association in which there is a common benefit (namely, the sustained separate advantages of each individual: the employer has a service performed, the employee receives a wage); a form of "friendship" (each likes what is useful in the other); and forms of justice to adjudicate when the relationship has gone awry (e.g., withholding wages because of non-performance of a task). That we can readily understand that the relationship between master and slave is different in kind from the relationship between an employer and employee-that, in the former, there is no common benefit between master and slave, and that there is neither friendship nor justice between the two-entails that Aristotle's distinction is a viable one.

Of course, just because a distinction is viable hardly requires that the things so distinguished are to be commended. In no way does my analysis support the claim that slavery is either just or beneficial. The benefit of my analysis is that it forces

${ }^{54}$ Kraut, Aristotle, 297. I am grateful to an anonymous reviewer for the Journal for underscoring the relevance of Kraut's arguments to my own position.

55 See further Simpson, "Defense," I I3-I 5. 
us to face what is truly wrong in Aristotle's analysis, rather than to be sidetracked by an apparent inconsistency in his argument. We tend to bestow personhood on all human forms of life (even those in need of guardians), but the institution of slavery characterizes a human being as a thing, rather than as a person. When confronted with such an institution-almost universal in the world he knew-Aristotle applied his sophisticated skills of analysis and suggested a viable distinction to make sense of how that institution characterized humans who were not persons. ${ }^{56}$ I suspect that it is easier to criticize the institution of slavery as inconsistent with personhood than it is to explain and justify why we should accord dignity and personhood to every human being as such. ${ }^{57}$ But if Aristotle's distinction between the benefit which accrues to a slave and that which accrues to an individual involved

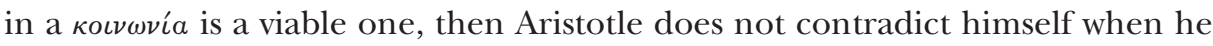
claims that natural slavery is beneficial to a slave, but that there is no common benefit between the slave and master. ${ }^{5}$

${ }^{56}$ Nagle (Households, I I7) writes-correctly, I think-that

Aristotle's analysis of slavery is not vitiated by false consciousness. Rather, he reflects accurately the real situation of the Mediterranean slave-owning world in which he lived. He is neither subtly undermining the practice of slavery nor overtly sustaining its legitimacy. $\mathrm{He}$ is merely, thoughtfully, stating what would have been obvious to the more aware of his contemporary hearers and readers, who were as familiar as he was with the realities of life and labor in the fourth century. In practice, the way to solve the problem of unjust enslavement, as everyone knew, was to manumit one's slaves minimally, as many, including Aristotle, did by testament.

${ }^{57}$ For a spirited comparison, see S. R. L. Clark, "Slaves, Servility, and Noble Deeds," Philosophical Inquiry 25 (2003): 165-76.

${ }^{58}$ I would like to thank D. Brendan Nagle, Marina McCoy, and two anonymous reviewers for the Journal for reading and commenting on previous drafts of this paper. 